\title{
Litterfall and litter chemistry change over time in an old-growth temperate forest, northeastern China
}

\author{
Xuefeng $\mathrm{LI}^{1}$, Yanling $\mathrm{HU}^{1,2}$, Shijie $\mathrm{HAN}^{1}{ }^{*}$, Ying $\mathrm{LIU}^{3}$, Yan $\mathrm{ZHANG}^{1}$ \\ ${ }^{1}$ Institute of Applied Ecology, Chinese Academy of Sciences, 72 Wenhua Road, Shenyang 110016, P.R. China \\ ${ }^{2}$ Graduate College of Chinese Academy of Sciences, 19 Yuquan Road, Beijing 100049, P.R. China \\ ${ }^{3}$ College of Light Industry and Food Sciences, South China University of Technology, 381 Wushan Road, Tianhe District, \\ Guangzhou 510641, P.R. China
}

(Received 10 February 2009; accepted 11 August 2009)

Keywords:

long-term observation /

litterfall /

litter chemistry /

forest floor properties /

old-growth temperate forest

Mots-clés :

observation à long terme /

chute de litière /

chimie de la litière /

propriétés du sol forestier /

vieille forêt tempérée

\begin{abstract}
- Litterfall and litter chemistry are key factors for the assessment of forest floor properties. A longterm study on litterfall, litter chemistry and forest basal areas was carried out in an old-growth temperate forest, northeastern China.

- The objective of this study was to test whether forest floor properties in the old-growth forest remain relatively constant.

- Litterfall increased significantly over the past 27 y but litterfall of various litter components showed different temporal trends. Changes in proportions of various litter components, combined with the inherent chemistry differences among them, made litter carbon $(\mathrm{C})$ : nitrogen $(\mathrm{N})$ and lignin: $\mathrm{N}$ ratios increase at an average rate of 0.19 and 0.16 per year, respectively, suggesting a decreasing trend in the forest floor $\mathrm{C}$ and $\mathrm{N}$ cycling rates. Changes in dominant tree species biomass significantly affected their corresponding foliar litter production and proportions in the total litterfall and therefore played a dominant role in regulating the developing trends of litter chemistry and quantity in this forest floor. - Our study indicated that forest floor properties in the old-growth forest still showed a directional change and this was mainly caused by the intrinsic changes rather than yearly climatic fluctuation.
\end{abstract}

Résumé - La chute de litière et la chimie de la litière changent au fil du temps dans une vieille forêt tempérée du Nord-Est de la Chine.

- Les chutes de litière et la chimie des litières sont des facteurs clés pour l'évaluation des propriétés de la couverture des sols forestiers. Une étude à long terme sur la chute des litières, la chimie des litières et les surfaces terrières a été effectuée dans une vieille forêt tempérée du nord-est de la Chine. - L'objectif de cette étude était de vérifier si les propriétés de la couverture du sol forestier dans la vieille forêt demeuraient relativement constantes.

- Les chutes de litière ont augmenté sensiblement au cours des 27 dernières années, mais les différentes composantes ont montré différents trends. Des changements dans les proportions de divers composants de la litière, associés à des différences de chimie entre eux, ont fait que les rapports carbone de litière $(\mathrm{C})$ : azote $(\mathrm{N})$ et lignine : $\mathrm{N}$ ont respectivement augmenté d'un taux moyen de 0,19 et 0,16 par an, ce qui suggère une tendance à la baisse dans le tapis forestier des taux des cycle de carbone et d'azote. Des changements, dans la biomasse des arbres des essences dominantes, ont considérablement affecté leur production de litière feuillue correspondante et les proportions dans la litière totale et ont donc joué un rôle dominant dans la régulation du développement des tendances de la chimie de la litière et de la quantité de litière dans ce tapis forestier.

- Notre étude a montré que les propriétés de la couverture du sol forestier dans la vieille forêt, ont encore montré un changement directionnel, ce qui a été principalement causé par des changements intrinsèques plutôt que par les fluctuations annuelles du climat.

\footnotetext{
*Corresponding author: hansj@iae.ac.cn
} 


\section{INTRODUCTION}

Litterfall and its subsequent bioelement return are key components in the functioning and stability of forest ecosystems (Berg, 2000; Edwards, 1982; Valdespino et al., 2009; Vitousek, 1984). Initial litter chemistry including carbon (C): nitrogen $(\mathrm{N})$ and lignin: $\mathrm{N}$ ratios are often correlated with the rate of litter decay and therefore the formation of soil organic matter (Fassnacht and Gower, 1999; Mo et al., 2008; Taylor et al., 1989). Thus, cumulative directional changes in litterfall and litter chemistry can profoundly influence the forest floor properties and therefore its developing trend (Ferrari, 1999; Raimundo et al., 2008). Forest litterfall varies greatly among years (Hennessey et al., 1992; Lin et al., 2003; Wright and Cornejo, 1990). Such variation can be attributed to interannual climatic variation (Kouki and Hokkanen, 1992; Lin et al., 2003) and the growth of the forest (Liao et al., 2000) or the combination of the two factors (Wen et al., 1990). Previous studies mainly focused on litterfall dynamics and its relationship with climatic factors but did not assess temporal changes in litter chemistry and its correlations with forest biomass and stand composition.

It is still unclear whether forest floor properties in oldgrowth forests remain relatively stable, and direct support from experiments is scarce. Studies using the space-for-time substitution method could not fully reflect the changes in forest floor properties because it involves many uncontrolled types of variations other than time including soil properties, geographical location and tree species density (Archambault et al., 1998; Schulze et al., 2005; Starr et al., 2005). Thus, a long-term in situ litterfall study is needed to fully test the above perception.

Korean pine (Pinus koraiensis Sieb. et Zucc.) -mixed broadleaf forest (KBMF) has existed for over one thousand years in the temperate region of northeastern Asia with highly complicated structure and diversity (Barnes et al., 1992; Wu, 1983). In this study, we used long-term in situ litterfall and forest inventory data to quantify the temporal trends of the litterfall and litter chemistry; to assess the extent to which yearly climatic fluctuation and forest biomass change can affect them; and to test whether the forest floor properties remain relatively constant with time in this forest.

\section{MATERIALS AND METHODS}

\subsection{Site description}

The long-term litterfall study was conducted in Changbai Mountain Reserve $\left(42^{\circ} 24^{\prime} 9^{\prime \prime} \mathrm{N}, 128^{\circ} 05^{\prime} 45^{\prime \prime} \mathrm{E}\right)$ in Jilin province, China. The Reserve covers an area of 216716 ha with elevation ranging from 500-2 $600 \mathrm{~m}$ above sea level. KBMF distributed over a 500-1 $100 \mathrm{~m}$ belt accounts for about half of the Reserve.

In 1979, the Institute of Applied Ecology, Chinese Academy of Sciences, chose about 30 ha undisturbed KBMF in the Reserve as an experimental site. The experimental site has an elevation of 730$780 \mathrm{~m}$ and a slope of $<5^{\circ}$. The climate is temperate monsoon, with a dry spring, hot and humid summer, cool and dry fall, and cold winter. Mean annual precipitation is about $700 \mathrm{~mm}$ and mean annual air temperature is $3.3\left({ }^{\circ} \mathrm{C}\right)$. The bedrock is a basalt platform that may be covered with deep volcanic ash, sands and gravels, or loess and the upper horizons are of loessal origin (Barnes et al., 1992; Cheng et al., 1981).

The mean dominant species height is about $30 \mathrm{~m}$. The dominant species in the upper canopy are Korean pine, bass (Tilia amurensis Rupr.), ash (Fraxinus mandshurica Rupr.), maple (Acer mono Maxim.) and oak (Quercus mongolica Fisch. ex Turoz.), with an average age of about 131, 140, 255, 190 and $187 \mathrm{y}$, respectively. The mean diameter at breast height for these dominant species is $0.29,0.31,0.55,0.49$ and $0.21 \mathrm{~m}$, respectively. The subdominant species are mainly composed of Acer tegmentosum Maxim., A. mandshuricum Maxim., Tilia mandshurica Rupr. et Maxim., Ulmus propinqua Koidz. var. suberosa Miyabe. and Phellodendron amurense Pupr. More information on the soil and vegetation can be found in Barnes et al. (1992).

\subsection{Litter experiment}

In 1980 , sixteen $1 \mathrm{~m} \times 1 \mathrm{~m}$ traps were established in the four $50 \mathrm{~m} \times 50 \mathrm{~m}$ subplots of the experimental forest. Traps consisted of a nylon net (1-mm mesh size) bag placed over the wood frame $(10 \mathrm{~cm}$ depth) and were randomly placed compared to trees. Each subplot had 4 traps, about $10 \mathrm{~m}$ apart and $50 \mathrm{~cm}$ above the ground. Litterfall study, as a part of long-term and on-site observation, was started in July of 1980. Litter was collected monthly and sorted into 8 kinds of litter components: including Korean pine needles, foliar litter of bass, ash, maple, oak, subdominant broadleaf species, twigs (including twigs and barks), and reproductive structures (including catkins, bracts, flowers and seeds). It should be noted that the cones of Korean pine were not included in total litterfall, because they were jointly picked by squirrels, other animals, and local inhabitants. Thus, reproductive structures in this study were actually from broadleaf species. After classification, each part was dried at $60{ }^{\circ} \mathrm{C}$ to a constant mass and weighed. Litterfall collection was discontinued in some years. As a result, 19 years' litterfall data were available excluding those in 1986, 1987, 1989, 1991, 1996, 1998, 1999 and 2000. We used climatic variables, basal areas of Korean pine $\left(\mathrm{BA}_{\text {pine }}\right)$, bass $\left(\mathrm{BA}_{\text {bass }}\right)$, ash $\left(\mathrm{BA}_{\text {ash }}\right)$, maple $\left(\mathrm{BA}_{\text {maple }}\right)$, oak $\left(\mathrm{BA}_{\text {oak }}\right)$ and subdominant broadleaf species $\left(\mathrm{BA}_{\text {sub }}\right)$, and the total $\left(\mathrm{BA}_{\text {total }}\right)$ to determine their possible impacts on the litterfall of the corresponding litter components.

Climatic variables used in this study are listed in Table I. Data were obtained from a forest meteorological observation station $1 \mathrm{~km}$ from the plot. The data on the dynamics of $\mathrm{BA}_{\text {pine }}, \mathrm{BA}_{\text {bass }}, \mathrm{BA}_{\text {ash }}$, $\mathrm{BA}_{\text {maple }}, \mathrm{BA}_{\text {oak }}, \mathrm{BA}_{\text {sub }}$ and $\mathrm{BA}_{\text {total }}$ were from forest inventories conducted in 1981, 1991, 1997 and 2005 in the permanent plots. The basal areas in years with no inventory data were estimated using an interpolation method based on the following equations:

$$
\begin{aligned}
& \mathrm{BA}_{i}=\mathrm{BA}_{1981}+(i-1981)\left(\mathrm{BA}_{1991}-\mathrm{BA}_{1981}\right) /(1991-1981) ; \\
& 1981<i<1991 \\
& \mathrm{BA}_{i}=\mathrm{BA}_{1991}+(i-1991)\left(\mathrm{BA}_{1997}-\mathrm{BA}_{1991}\right) /(1997-1991) ; \\
& \quad 1991<i<1997 \\
& \mathrm{BA}_{i}=\mathrm{BA}_{1997}+(i-1997)\left(\mathrm{BA}_{2005}-\mathrm{BA}_{1997}\right) /(2005-1997) ; \\
& \quad 1997<i \leq 2007,
\end{aligned}
$$

where $\mathrm{BA}_{i}$ is basal area in year $i, i=1981,1982, \ldots, 2007$.

For chemical analysis, foliar litters were only sampled in fall because over $95 \%$ of foliar litterfall occurred in this season, while broadleaf species' reproductive structures and twigs were sampled in 
Table I. Climatic factors used in this study and their corresponding codes.

\begin{tabular}{lc}
\hline Climatic factors & Code \\
\hline Annual precipitation in current year & $\mathrm{Pr}$ \\
Annual accumulated temperature $\left(>5^{\circ} \mathrm{C}\right)$ in current year & $\mathrm{Tem}$ \\
Annual precipitation in previous litterfall year & $\mathrm{Pr}_{-1}$ \\
Annual accumulated temperature $\left(>5^{\circ} \mathrm{C}\right)$ in previous & \\
litterfall year & $\mathrm{Tem}_{-1}$ \\
\hline
\end{tabular}

both spring and fall. Litter chemistry for each litter component has been determined every year since 2001. Samples for each litter component were collected from each litter trap and ground using an intermediate mill $(0.5-\mathrm{mm}$ mesh screen) to generate homogeneous and composite samples for chemical analysis. $\mathrm{N}$ was determined using a modified Kjeldahl method followed by photometric analysis. C concentration was determined using an element analyzer (Vario EL III, Elementar, Germany). Lignin was estimated by modified gravimetry based on a standardized method using hot sulfuric acid digestion (King and Heath, 1967). Data of C, N and lignin concentrations in each litter component before 2001 in this forest ecosystem were from chemical analysis conducted in Cheng et al. (1984; 1992), Geng (1987), Xu et al. (1994), and Li (1995). Data from the previous reports and the last 7 years' chemical analysis were averaged to estimate mean annual litter $\mathrm{C}: \mathrm{N}$ and lignin: $\mathrm{N}$ ratios. However, broadleaf species' reproductive structures were not included in the estimation of total litter chemistry.

Annual litter C:N and lignin: $\mathrm{N}$ ratios were calculated by the following equation:

$$
\mathrm{AR}=\sum \mathrm{P}_{i} / \sum \mathrm{N}_{i} ; i=1,2, \ldots, 7
$$

where $A R$ is the litter $C: N$ or lignin: $N$ ratio, $P_{i}$ is the amount of $\mathrm{C}$ or lignin of the $i$ th litter component and $\mathrm{N}_{i}$ is the amount of $\mathrm{N}$ of the $i$ th litter component.

\subsection{Statistical analyses}

Pearson's correlation analysis $(n=19)$ was used to determine the relationships among litterfall of various litter components and dominant tree species basal areas and climatic factors. The relationships between percent contribution of each litter component and the corresponding relative basal area were also examined. To explore the temporal change in litter $\mathrm{C}: \mathrm{N}$ and lignin: $\mathrm{N}$ ratios, a linear regression model was performed between the litter $\mathrm{C}: \mathrm{N}$ or lignin: $\mathrm{N}$ ratio and years. The annual average changing rate was represented by the slope (St). In addition, each litter component was individually ruled out from the total litterfall, and then the temporal changes in the litter $\mathrm{C}: \mathrm{N}$ and lignin: $\mathrm{N}$ ratios were calculated. The linear regression model was performed again to compute the slope value $\left(\mathrm{St}_{i} ; i=1,2, \ldots\right.$, 7). The impact of each of the 7 litter components on the litter $C: N$ and lignin: $\mathrm{N}$ ratios was quantified by determining the difference (DI) between $\mathrm{St}$ and $\mathrm{St}_{i}$. The existence of a certain litter component was considered to improve the increasing rate of the litter $\mathrm{C}: \mathrm{N}$ or lignin: $\mathrm{N}$ ratio if its slope was lower than St. In all cases, significant effects were determined at the 0.05 probability level. All statistical analysis was performed using SPSS software.

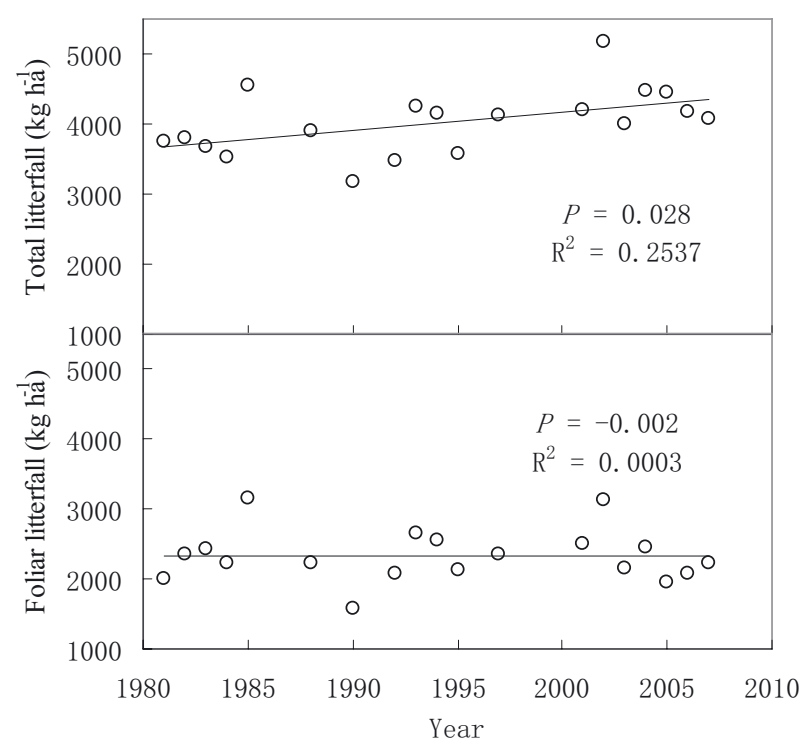

Figure 1. Annual changes in total and foliar litterfall.

\section{RESULTS}

\subsection{Litterfall}

Total litterfall ranged from $3147.4 \mathrm{~kg} \mathrm{ha}^{-1}$ to $5166.1 \mathrm{~kg} \mathrm{ha}^{-1}$ (Fig. 1) with an average of $4023 \mathrm{~kg} \mathrm{ha}^{-1}$. On average, the broadleaf litter was the largest component, accounting for $58 \%$ of the total litterfall, followed by needles $(19 \%)$, twigs $(13 \%)$ and broadleaf reproductive structures (10\%). Ash leaves were the largest leaf component, accounting for $18 \%$ of the total litterfall, followed by maple $(16 \%)$, subdominant broadleaf $(10 \%)$, oak $(8 \%)$ and bass $(6 \%)$ leaves. A significant negative correlation was found between broadleaf litterfall of leaves and reproductive structures ( $R=-0.70, P<0.001 ; n=19)$, reflecting an asynchronous optimum production between them.

Total litterfall increased significantly over time (Fig. 1). Twig litterfall showed a significantly increasing trend, while broadleaf reproductive structure and foliar litterfall fluctuated greatly around the means (Figs. 1,2). Foliar litterfall from different tree species showed various overall trends. Foliar litterfall of ash and bass exhibited an evident decreasing trend, while others showed an increasing trend, especially for needles, which increased significantly over time (Fig. 2). The percent contributions of needle and twig litterfall to the total exhibited a significantly increasing trend, but the reverse pattern was found for those of ash and bass. The other four litter components did not show evidently temporal trends (Fig. 3).

\subsection{Basal area}

$\mathrm{BA}_{\text {pine }}, \mathrm{BA}_{\text {bass }}, \mathrm{BA}_{\text {maple }}, \mathrm{BA}_{\text {oak }}$ and $\mathrm{BA}_{\text {sub }}$ increased continuously over time, while $\mathrm{BA}_{\text {ash }}$ declined slightly from 1997 to 2005 (Fig. 4). The relative basal areas of the five dominant species varied from 1981 to 2005, with Korean pine showing a 


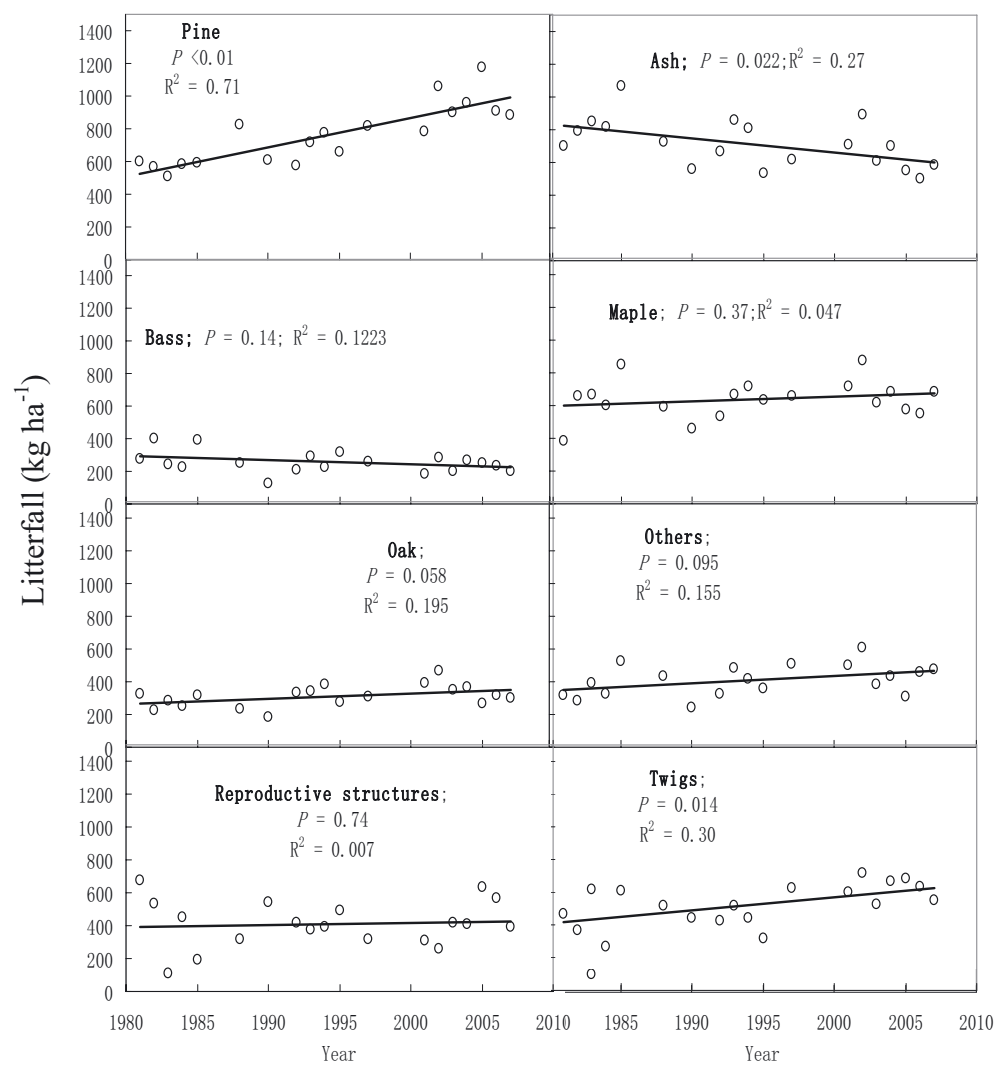

Figure 2. Temporal changes in litterfall of various litter components.

Table II. The $R$ values for the relationship between litterfall of various litter components and the corresponding basal area (Coefficient 1) and the relationship between the percent contribution of each litter component and the corresponding relative basal area (Coefficient 2).

\begin{tabular}{lcc}
\hline Relationship Types & Coefficient 1 & Coefficient 2 \\
\hline${\text { Ash- } \mathrm{BA}_{\text {ash }}}_{\text {Bass- }} \mathrm{BA}_{\text {bass }}$ & $-0.48^{*}$ & $0.83^{* *}$ \\
${\text { Oak- } \mathrm{BA}_{\text {oak }}}$ & -0.31 & $0.53^{*}$ \\
Maple- $\mathrm{BA}_{\text {maple }}$ & 0.45 & 0.20 \\
Pine- $\mathrm{BA}_{\text {pine }}$ & 0.23 & 0.11 \\
Subdominant species- $\mathrm{BA}_{\text {sub }}$ & $0.84^{* *}$ & $0.81^{* *}$ \\
Twigs- $\mathrm{BA}_{\text {total }}$ & 0.41 & 0.25 \\
Reproductive structures-BA $_{\text {broadleaf }}$ & $0.56^{*}$ & \\
Total-BA $_{\text {total }}$ & 0.08 & \\
\hline
\end{tabular}

$* P<0.05, * * P<0.01$.

marked increasing trend and ash exhibiting a decreasing trend (Fig. 4). Foliar litterfall of ash and bass showed negative relationships with their corresponding basal areas, while foliar litterfall produced by oak, maple and subdominant species, and Korean pine had positive relationships with their corresponding basal areas (Tab. II). Twig and total litterfall were positively and significantly related to $\mathrm{BA}_{\text {total }}$ (Tab. II). The percent contributions of foliar litterfall from Korean pine, ash and bass to the total were significantly related to the relative basal areas of the three tree species (Tab. II).
Table III. Relationships among climatic factors and litterfall of various litter components.

\begin{tabular}{lcccc}
\hline Litter components & $\mathrm{Pr}$ & $\mathrm{Tem}$ & $\mathrm{Pr}_{-1}$ & $\mathrm{Tem}_{-1}$ \\
\hline Ash & $-0.50^{*}$ & 0.33 & 0.16 & -0.23 \\
Bass & -0.07 & 0.11 & 0.31 & -0.25 \\
Oak & -0.3 & 0.09 & -0.14 & -0.08 \\
Maple & $-0.47^{*}$ & 0.35 & -0.03 & 0.21 \\
Subdominant species & -0.38 & 0.26 & -0.28 & 0.22 \\
Pine & 0.13 & -0.16 & -0.27 & 0.32 \\
Twigs & 0.03 & -0.06 & -0.26 & 0.32 \\
Broadleaf & & & & \\
reproductive structures & $-0.46^{*}$ & -0.29 & 0.03 & -0.26 \\
Total & -0.41 & 0.12 & -0.22 & 0.25 \\
\hline
\end{tabular}

$* P<0.05, * * P<0.01$.

\subsection{Correlations among climatic factors and litterfall}

Litterfall of ash, maple and reproductive structures were sensitive to annual precipitation (Tab. III). Litterfall of the other five litter components and total litterfall were not significantly related to the climatic factors used in this study (Tab. III).

\subsection{Litter quality}

Litter chemistry among various litter components were highly variable (Tab. IV), with needles and twigs having a 


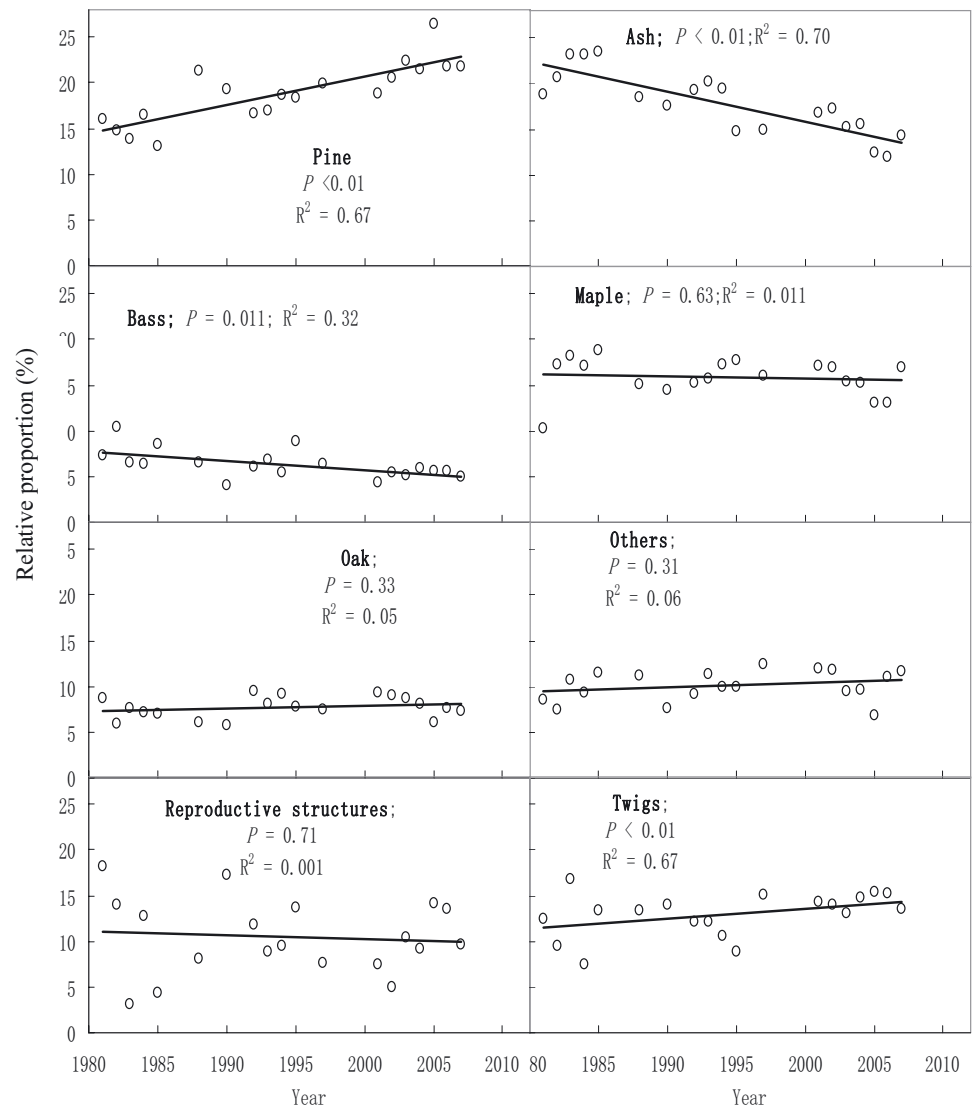

Figure 3. Temporal changes in the proportions of various litter components in the total litterfall (\%).

Table IV. Mean $( \pm 1 \mathrm{SE}) \mathrm{C}, \mathrm{N}$ and lignin concentrations $\left(\mathrm{mg} \mathrm{g}^{-1}\right), \mathrm{C}: \mathrm{N}$ ratio and lignin:N ratio of litterfall components in Korean pine-mixed broadleaf forest.

\begin{tabular}{lccccc}
\hline $\begin{array}{l}\text { Litter } \\
\text { components }\end{array}$ & $\begin{array}{c}\mathrm{C} \\
\text { concentration }\end{array}$ & $\begin{array}{c}\mathrm{N} \\
\text { concentration }\end{array}$ & $\begin{array}{c}\text { Lignin } \\
\text { concentration }\end{array}$ & $\begin{array}{c}\text { C:N } \\
\text { ratio }\end{array}$ & $\begin{array}{c}\text { Lignin:N } \\
\text { ratio }\end{array}$ \\
\hline Ash & $443(5)$ & $14.5(1.5)$ & $157(6)$ & 30.6 & 10.8 \\
Bass & $471(9)$ & $13.9(1.3)$ & $166(12)$ & 33.9 & 11.9 \\
Oak & $492(3)$ & $8.3(0.8)$ & $221(15)$ & 59.3 & 26.6 \\
Maple & $447(12)$ & $10.2(0.6)$ & $149(9)$ & 43.8 & 14.6 \\
Subdominant species & $494(5)$ & $11.8(1.2)$ & $205(11)$ & 41.9 & 17.4 \\
Pine & $511(8)$ & $7.5(0.7)$ & $291(13)$ & 68.1 & 38.8 \\
Twigs & $501(9)$ & $4.7(0.6)$ & $362(16)$ & 106.6 & 77.0 \\
Reproductive structures & $488(6)$ & $9.5(1.8)$ & $240(11)$ & 51.4 & 25.3 \\
\hline
\end{tabular}

higher lignin concentration, lignin: $\mathrm{N}$ ratio and $\mathrm{C}: \mathrm{N}$ ratio, and lower $\mathrm{N}$ concentration compared with broadleafs and reproductive structures. The $\mathrm{C}: \mathrm{N}$ ratio and lignin: $\mathrm{N}$ ratio increased between 1981 and 2007 from about 45 to 51 and 25 to 30, at an average rate of 0.19 and 0.16 per year, respectively, which were significantly different from 0 at the 0.05 significance level (Fig. 5).

Korean pine needles played a dominant role in affecting the temporal trend of litter chemistry, which improved the annual increasing rates of the $C: N$ ratio and lignin: $N$ ratio to 0.21 and 0.12 , respectively (Tab. V). Twig existence increased the C:N and lignin: $\mathrm{N}$ ratios by average rates of 0.11 and 0.06 per year, respectively (Tab. V). In contrast, the existence of ash leaves made the $\mathrm{C}: \mathrm{N}$ ratio and lignin: $\mathrm{N}$ ratio decrease significantly, with average rates of 0.10 and 0.06 per year, respectively (Tab. V).

\section{DISCUSSION}

\subsection{Litterfall dynamics}

Litterfall of all components and total litterfall varied greatly between years (Fig. 1), which were consistent with a long-term litterfall study conducted in a subtropical evergreen broadleaved forest (Guan et al., 2004). Previous litterfall studies 
Table V. Linear regression analysis of litter C:N and lignin: $\mathrm{N}$ ratios against years.

\begin{tabular}{lccc}
\hline Litter components & Regression & $R^{2}$ & DI \\
\hline \multirow{2}{*}{ Total litterfall } & $\mathrm{C}: \mathrm{N}=0.19$ Year -333 & 0.54 & \\
& Lignin $: \mathrm{N}=0.16$ Year -291 & 0.50 & \\
Excluding ash leaves & $\mathrm{C}: \mathrm{N}=0.29$ Year -539 & 0.64 & 0.10 \\
& Lignin $: \mathrm{N}=0.22$ Year -419 & 0.63 & 0.06 \\
Excluding bass leaves & $\mathrm{C}: \mathrm{N}=0.23$ Year -403 & 0.55 & 0.04 \\
& Lignin: $\mathrm{N}=0.20$ Year -371 & 0.58 & 0.04 \\
Excluding maple leaves & $\mathrm{C}: \mathrm{N}=0.21$ Year -364 & 0.39 & 0.02 \\
& Lignin $: \mathrm{N}=0.19$ Year -356 & 0.53 & 0.03 \\
Excluding oak leaves & $\mathrm{C}: \mathrm{N}=0.18$ Year -309 & 0.43 & -0.01 \\
& Lignin: $\mathrm{N}=0.18$ Year -332 & 0.50 & 0.02 \\
Excluding subdominant species leaves & $\mathrm{C}: \mathrm{N}=0.17$ Year -300 & 0.56 & -0.02 \\
& Lignin: $\mathrm{N}=0.18$ Year -333 & 0.53 & 0.02 \\
Excluding needles & $\mathrm{C}: \mathrm{N}=-0.02$ Year -77 & 0.02 & -0.21 \\
& Lignin: $=0.04$ Year -59 & 0.069 & -0.12 \\
Excluding twigs & $\mathrm{C}: \mathrm{N}=0.08$ Year -112 & 0.20 & -0.11 \\
& Lignin: $\mathrm{N}=0.10$ Year -187 & 0.37 & -0.06 \\
\hline
\end{tabular}

* DI is the differences between $\mathrm{St}_{\text {and }} \mathrm{St}_{i}(i=1,2, \ldots, 7)$. St stands for the slope of linear regression model calculated from all litter components and $\mathrm{St}_{i}$ is the slope calculated after a certain litter component was excluded.

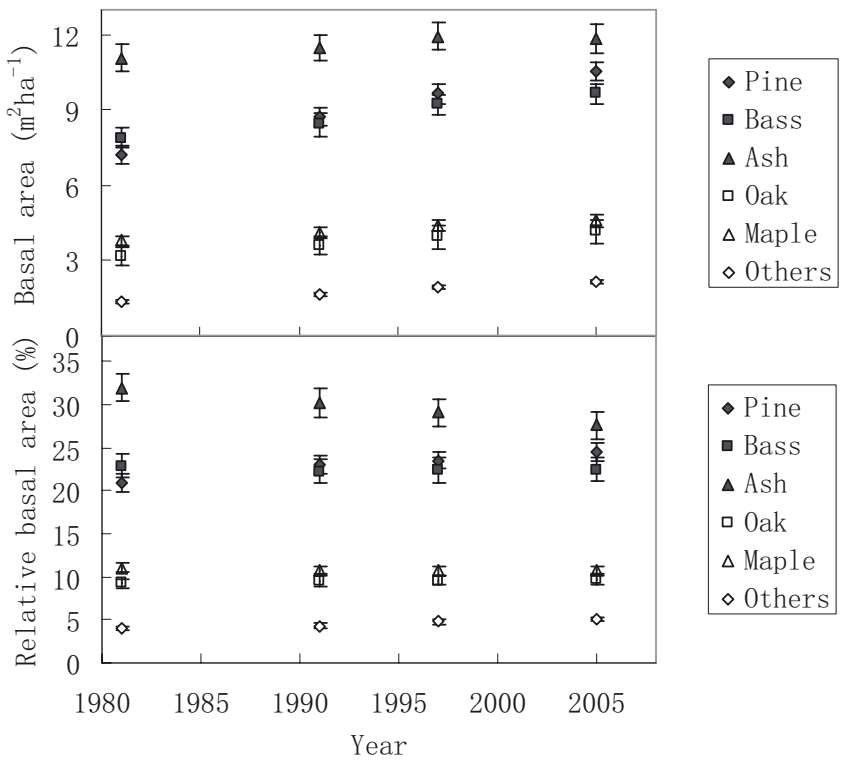

Figure 4. Temporal changes in basal areas of dominant species and their percent contributions to the total basal area.

indicated that climate can significantly affect the forest litterfall. Typhoon (Lin et al., 2003), temperature (Kouki and Hokkanen, 1992), flood (Haase, 1999), drought (Wright and Cornejo, 1990) and a combination of temperature, precipitation and wind speed (Hennessey, 1992; Wen et al., 1990) were proved to be significant factors regulating forest litterfall. In this study, we found that climate could affect annual litterfall because litterfall of ash, maple and broadleaf reproductive structures were significantly related to Pr (Tab. III). The fact that foliar litterfall from different species responded differently to climatic effects reflected various eco-physiological characteristics among these tree species (Tab. III).

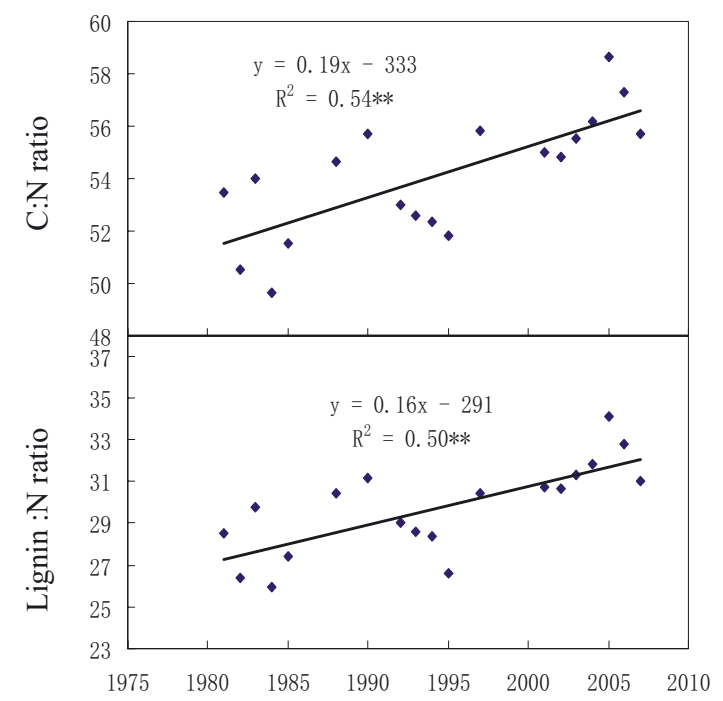

Figure 5. Temporal changes in litter $\mathrm{C}: \mathrm{N}$ and lignin: $\mathrm{N}$ ratios.

We speculated that yearly variation in litterfall may in part be ascribed to a self-regulating mechanism in the forest. This hypothesis was supported by the litterfall data in our study, with evidence that broadleaf litters were significantly and negatively related to broadleaf reproductive structures. The negative relationship between leaf litters and reproductive structures was also found in a subtropical forest in southern China ( $r=-0.35 ; p=0.14 ; n=20$ ) (Guan et al., 2004). The relatively weak relationship in Guan et al. (2004) may be due to the fact that forests are often influenced by typhoons in that area, which always causes a large amount of litterfall and therefore disturbs trees' growth rhythm (Zhang et al., 2000). This asynchronous optimum production between broadleaf litter and reproductive structures is probably because trees cannot invest ample resources in both parts. Trees generally take 
more resources to produce a certain amount of reproductive structures than to produce the same amount of leaves (Spurr and Barnes., 1973). As a result, total litterfall is generally lower in the years with higher reproductive structures than the years with higher foliar litters.

Studies using the space-for-time substitution method suggested that forest litterfall was lower in the late developing stage than in the previous developing stage (Zhang et al., 2000). A twenty-year litterfall study also showed that total litterfall and foliar litterfall decreased over time in an old subtropical forest (Guan et al., 2004). In contrast, litterfall in this study increased gradually as the forest aged, suggesting that litterfall in KBMF still increases with time. However, this was mainly caused by the increment in Korean pine needles and twigs, because other litter components did not show an evident increasing trend. Our study provided direct evidence to prove that the twig litterfall and its proportion in the total increased with time in this forest (Figs. 2 and 3). This was partly consistent with the result of Guan et al. (2004) who found that the contribution of woody materials to the total litterfall increased with time. The difference in litterfall dynamics among KBMF and other forest ecosystems (Guan et al., 2004; Zhang et al., 2000) indicates that litterfall in different forests does not show the same temporal trend.

\subsection{Climatic impact on litterfall and litter quality}

Climate has been regarded as one of the key factors regulating the litterfall and amounts of nutrients returned in some forest ecosystems (Haase, 1999; Hennessey, 1992; Kouki and Hokkanen, 1992; Lin et al., 2003; Wen et al., 1990; Wright and Cornejo, 1990). Our study showed that climatic variation did not substantially alter the dynamics of total litterfall and litter $\mathrm{C}: \mathrm{N}$ and lignin: $\mathrm{N}$ ratios in KBMF. The reasons for it were as follows. First, climatic factors only significantly impacted three litter components, which accounted for less than $25 \%$ of annual litterfall variations. Second, these litter components played a minor role in regulating litter $\mathrm{C}: \mathrm{N}$ and lignin: $\mathrm{N}$ ratios compared with needles and twigs, as indicated by the value of DI (Tab. V). Last, the climate in this region had not shown an evident temporal tendency in the past $240 \mathrm{y}$. Thus, it was unlikely to have had a great impact on these litter components (Yu et al., 2005; Zhang et al., 2007).

\subsection{Effect of change in basal area on litterfall and litter quality}

Despite no variation in species richness, the dominant species' basal area and their proportions in the total still changed over time and different species showed various overall trends (Fig. 4), suggesting that not all the dominant species in this forest attained the mature stage. A previous study conducted in an old-growth temperate forest in Washington showed that needle litterfall was related to basal area (Edmonds and Murry, 2002). This is generally consistent with this study (Tab. II). The temporal changes in the absolute and relative basal areas of major tree species affected the litterfall of certain litter components and their relative proportions in the total. Litter chemistry differed greatly among litter components (Tab. IV). This is the reason that changes in the relative proportion of litter components rather than litterfall play a more important role in regulating litter chemistry. $\mathrm{BA}_{\text {total }}$, $\mathrm{BA}_{\text {ash }}$ and $\mathrm{BA}_{\text {pine }}$ were significantly correlated with twig, ash and needle litterfall, respectively (Tab. II), the existence of which significantly changed the annual increasing rates of the $\mathrm{C}: \mathrm{N}$ and lignin: $\mathrm{N}$ ratios (Tab. III). Thus, changes in basal areas could play a more important role in affecting litter chemistry than climate. The ash and bass leaf litterfall had negative relationships with their respective basal areas, while Korean pine needles showed the opposite trend. This could be ascribed to their age structures. Bass and ash have an average age of 140 and $255 \mathrm{y}$ and a life span of 300 and $500 \mathrm{y}$, respectively, suggesting that both species have reached the mature stage. As a result, ash and bass leaf litterfall would decrease over time. In contrast, Korean pine has a life span of over 500 y (Wu, 1983), which is much higher than its mean age (131 years old) in this forest, indicating that it is still at the growing stage. Thus, the increment in $\mathrm{BA}_{\text {pine }}$ improved the needle litterfall and therefore its proportion in the total.

\subsection{Implications for the $\mathrm{C}$ and $\mathrm{N}$ cycling models}

Our study detected a measurable change in litter chemistry in this forest although there were no evident changes in species diversity. Changes in litterfall and litter chemistry were comparable with or even bigger than those among different forest types (Yang et al., 2005). Thus, studies on the temporal changes in forest floor properties using the space-for-time substitution method may not be reliable. The increase in litter C:N and lignin: $\mathrm{N}$ ratios with time in this forest indicates that $\mathrm{C}$ and $\mathrm{N}$ cycling rates tend to decrease as the forest matures. The directional change in litter chemistry in such a relatively short period will alter the forest floor properties and nutrient cycling rates (Edwards, 1982; Ferrari, 1999), and, hence, affect the soil properties. Thus, the temporal changes in litter chemistry should be incorporated into models for predicting the longterm changes in forest species composition or nutrient cycling rates.

\section{CONCLUSIONS}

The asynchronous optimum production between broadleaf litters and reproductive structures combined with yearly climatic variation had a great impact on annual litterfall. This has consequences for understanding the great variations in annual litterfall. Korean pine needle and woody material litterfall increased over time, which caused an increment in total litterfall and litter $\mathrm{C}: \mathrm{N}$ and lignin: $\mathrm{N}$ ratios. Both forest biomass and species composition, as indicated by the absolute and relative basal area of major species, still change with time in this forest. Without the occurrence of catastrophic disturbances, the intrinsic changes within the forest rather than external climatic fluctuation play a dominant role in orienting the temporal changes in litter chemistry and, in turn, the forest floor 
properties. Importantly, since litter chemistry changes greatly over time, it can be concluded that the relatively constant forest floor properties in this old-growth forest are unattainable.

Acknowledgements: We thank the staff of Changbai Mountain Research Station who were involved in this study for help in collecting and processing litter. Litterfall data provided by the Institute of Applied Ecology, Chinese Academy of Sciences is also appreciated. This study was jointly founded by the State Key Basic Research Project (Grant No. 2002CB412502), the State Key Basic Research Project (No. 90411021), the Innovation Study Key Project of the Chinese Academy of Sciences (No. KZCX1-SW-01- 01), and the Initiative Research Foundation of Doctorates granted by the Institute of Applied Ecology, Chinese Academy of Sciences (O7SBS112S350602).

\section{REFERENCES}

Archambault L., Morissette J., and Bernier-Cardou M., 1998. Forest succession over a 20-year period following clearcutting in balsam fir-yellow birch ecosystems of eastern Quhbec, Canada. For. Ecol. Manage. 102: 61-74.

Barnes B.V., Xu Z.B., and Zhao S.D., 1992. Forest ecosystems in an oldgrowth pine-mixed hardwood forest of the Changbai Shan Preserve in northeastern China. Can. J. For. Res. 22: 144-160.

Berg B., 2000. Litter decomposition and organic matter turnover in northern forest soils. For. Ecol. Manage. 133: 13-22.

Cheng B.R., Xu G.S., Ding G.F., and Zhang Y.H., 1981. The main soil groups and their properties of the natrue reserve on the northern slope of Changbai Mountain. Changbai Mountain Research Station of Forest Ecosystem, Institute of Forestry and Soil Sciences, Shenyang. Res. For. Ecosyst. 2: 196-206 (in Chinese).

Cheng B.R., Xu G.S., Ding G.F., Zhang Y.H. and Wang W., 1984. Litter production and nutrient contents in main forest ecosystems in Changbai mountain. Changbai Mountain Research Station of Forest Ecosystem, Institute of Forestry and Soil Sciences, Shenyang. Res. For. Ecosyst. 4: 19-23 (in Chinese).

Cheng B.R., Ding G.F., Xu G.S., and Zhang Y.H., 1992. Biological nutrient cycling in Korean pine-broadleaved forest of the Changbai mountain. Changbai Mountain Research Station of Forest Ecosystem, Institute of Forestry and Soil Sciences, Shenyang. Res. For. Ecosyst. 6: 185-193 (in Chinese).

Edmonds R.L. and Murray G.L.D., 2002. Overstory litter inputs and nutrient returns in an old-growth temperate forest ecosystem, Olympic National Park, Washington. Can. J. For. Res. 32: 742-750.

Edwards P.J., 1982. Studies of mineral cycling in a montane rain forest in New Guinea. V. Rates of cycling in throughfall and litter fall. J. Ecol. 65: 971-992.

Fassnacht K.S. and Gower S.T., 1999. Comparison of the litterfall and forest floor organic matter and nitrogen dynamics of upland forest ecosystems in north central Wisconsin. Biogeochemistry 45: 265284.

Ferrari J.B., 1999. Fine-scale patterns of leaf litterfall and nitrogen cycling in an old-growth forest. Can. J. For. Res. 29: 291-302.

Geng X.Y., Paster J., and Dewey B., 1993. Study on leaves decomposition of some tree species in Changbai mountain. Acta Phytoecol. Geobot. Sinica 17: 90-96 (in Chinese with English abstract).

Guan L.L., Zhou G.Y., Zhang D.Q., Liu X.J., and Zhang Q.M., 2004. Twenty years of litterfall dynamics in subtropical evergreen broadleaved forests at the Dinghushan forest ecosystem research station. Acta Phytoecologica Sinica 28 (4): 449-456 (in Chinese with English abstract).

Haase R., 1999. Littterfall and nutrient return in seasonally flooded and non-flooded forest of the Pantanal, Mato Grosso, Brazil. For. Ecol. Manage. 117: 129-147.

Hennessey T.C., Dougherty P.M., Cregg B.M., and Wittwer R.F., 1992. Annual variation in needle fall of a loblolly pine stand in relation to climate and stand density. For. Ecol. Manage. 51: 329-338.
King H.G.C. and Heath G., 1967. The chemical analysis of small samples of leaf material and the relationship between the disappearance and composition of leaves. Pedobiologia 7: 192-197.

Kouki J. and Hokkanen T., 1992. Long-term needle litterfall of a Scots pine (Pinus sylvestris) stand: relation to temperature factors. Oecologia 89: 176-181.

Li Y.W., 1995. Biochemical studies on the nitrogen cycle processes of forest (I). Acta Ecol. Sin. 15, Supp.(B): 31-40 (in Chinese with English abstract).

Liao L.P., Wang S.L., and Chen C.Y., 2000. Dynamics of litterfall in the mixed plantation of Michelia macclure $i$ and Cunningghamia lanceolata: a ten-year's observation. Chin. J. Appl. Ecol. 11 (Supp.): 131136 (in Chinese with English abstract).

Lin K.C., Steven P., Tang S.L., Hsia Y.J., and Lin T.C., 2003. Typhoon effects on litterfall in a subtropical forest. Can. J. For. Res. 33: 2184 2192.

Mo J., Fang H., Zhu W., Zhou G., Lu X., and Fang Y., 2008. Decomposition responses of pine (Pinus massoniana) needles with two different nutrient-status to $\mathrm{N}$ deposition in a tropical pine plantation in southern China. Ann. For. Sci. 65: 405.

Raimundo F., Martins A., and Madeira M., 2008. Decomposition of chestnut litterfall and eight-year soil chemical changes under a notillage management system in Northern Portugal, Ann. For. Sci. 65: 408.

Schulze E.-D., Wirth C., Mollicone D., and Ziegler W., 2005. Succession after stand replacing disturbances by fire, wind throw, and insects in the dark Taiga of Central Siberia. Oecologia 146: 77-88.

Spurr S.H. and Barnes B.V., 1973. Forest ecology, 2ed, The Ronald Press Company, New York, $560 \mathrm{p}$.

Starr M., Saarsalmi A., Hokkanen T., Merilä P., and Helmisaai H.S., 2005. Models of litterfall production for Scots pine (Pinus sylvestris) in Finland using stand, site and climate factors. For. Ecol. Manage. 205: 215-225.

Taylor B.R., Parkinson D., and Parsons W.J.F., 1989. Nitrogen and lignin content as predictors of litter decay rates: a microcosm test. Ecology 70: $97-104$.

Valdespino P., Romualdo R., Cadenazzi L., and Campo J., 2009. Phosphorus cycling in primary and secondary seasonally dry tropical forests in Mexico. Ann. For. Sci. 66: 107.

Vitousek P.M., 1984. Litterfall, nutrient cycling and nutrient limitation in tropical forests. Ecology 65: 285-298.

Wen Y.G., Wei S.Z., and Qin W.M., 1990. Analysis on the litter-fall dynamics of Chinese fir plantation and its correlation to climatic factors in north Guangxi. Acta Ecol. Sin. 10: 367-72 (in Chinese with English abstract).

Wright S.J. and Cornejo F.H., 1990. Seasonal drought and leaf fall in a tropical forest. Ecology 71: 1165-1175.

Wu Z.Y., 1983. Vegetation of China. Scientific Press, Beijing, 930 p., (in Chinese).

Xu G.B., Chen B.R., Ding G.F., and Zhang Y.H., 1994. Accumulation and decomposition of litterfall in a Korean pine-broadleaved forest stand. Changbai Mountain Research Station of Forest Ecosystem, Institute of Forestry and Soil Sciences, Shenyang. Res. For. Ecosyst. 7: 55-61 (in Chinese).

Yang W.Q., Wang K.Y., Kellomaki S., and Gong H.D., 2005. Litter dynamics of three Subalpine forests in western Sichuan. Pedosphere 15(5): 653-659.

Yu D.P., Wang S.Z., Tang L.N., Dai L.M., Wang Q.L., and Wang S.X., 2005. Relationship between tree-ring chronology of Larix olgensis and in Changbai Mountains and the climate change. Chin. J. Appl. Ecol. 16(1): 14-20 (in Chinese with English abstract).

Zhang D.Q., Ye W.H., Yu Q.F., Kong G.H., and Zhang Y.C., 2000. The litterfall of representivie forests of successional series in Dinghushan. Acta Ecol. Sin. 20: 938-944 (in Chinese with English abstract).

Zhang H.S., Han S.J., Li Y.W., and Zhang J.H., 2007. Reconstruction of temporal variations of precipitation in Changbai Mountain area over past 240 years by using tree-ring width data. Chin. J. Ecol. 26(2): 1924-1929 (in Chinese with English abstract). 